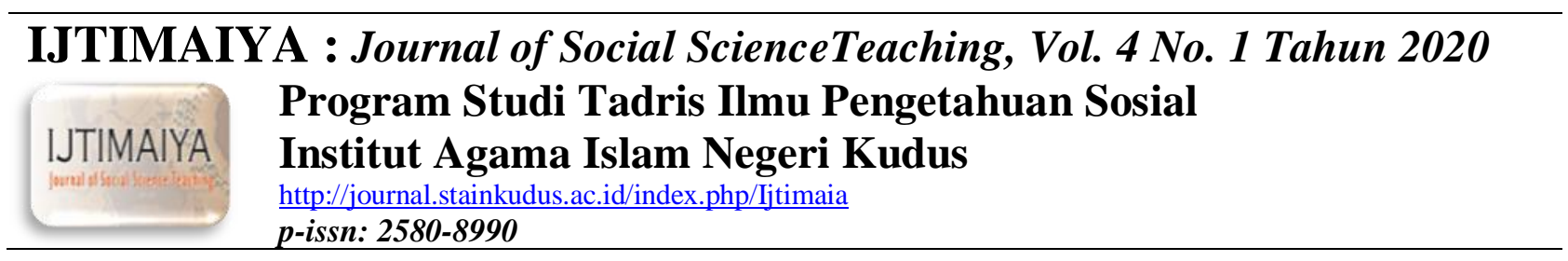

\title{
Upaya Meningkatkan Kemampuan Berfikir Siswa Melalui Implementasi Metode Problem Solving Pada Mata Pelajaran IPS di Mi NU Tamrinul Aulad Kudus
}

\author{
Durrotun Nafisah $^{\text {a, } 1}$, Sanusi ${ }^{\text {b, } 2}$ \\ aPGMI IAIN Kudus, Nafvir24@gmail.com \\ bIAIN Kudus, $\underline{\text { sanusipasca@gmail.com }}$
}

\begin{tabular}{ll}
\hline & ABSTRAK \\
\hline & Penelitian ini bertujuan untuk melihat secara nyata proses dan implementasi metode \\
Kata kunci: & problem solving sebagai upaya meningkatkan kemampuan berfikir siswa pada mata \\
Kemampuan & pelajaran Ilmu Pengetahuan Sosial (IPS)di MI NU Tamrinul Aulad Kudus. Jenis \\
berfikir & penelitian ini adalah penelitian lapangan dengan pendekatan kualitatif. Lokasi penelitian \\
Metode Problem & di MI NU Tamrinul Aulad Janggalan Kudus. Hasil penelitian ini menunjukkan bahwa: \\
Solving & (1) Pembelajaran IPS di MI Tamrinul Aulad Kudus itu disesuaikan dengan Kurikulum \\
& KTSP, tetapi untuk kelas I dan IV sudah mulai menerapkan Kurikulum 2013, (2) \\
& Penerapan metode problem solving di MI NU Tamrinul Aulad Kudus menjadikan siswa \\
& lebih aktif berpikir, aktif dalam pembelajaran di kelas dan bersemangat, (3) Faktor \\
& pendukung metode problem solving yaitu: peran guru, kemampuan untuk memahami \\
& kajian, keaktifan siswa, keefektifan metode, kesiapan anak didik, dan kecerdasan siswa. \\
& Faktor penghambat metode problem solving pada mata pelajaran IPS, yaitu: kurangnya \\
& motivasi siswa, kurangnya dukungan guru, dan kurangnya konsentrasi siswa.
\end{tabular}
ABSTRACT

Keyword:
Thinking ability
Problem Solving
Method

\begin{abstract}
This study aims to clearly see the process and implementation of problem solving methods as an effort to improve students' thinking skills in Social Sciences (IPS) subjects at MI NU Tamrinul Aulad Kudus. This type of research is field research with a qualitative approach. Research location at MI NU Tamrinul Aulad Janggalan Kudus. The results of this study indicate that: (1) Social Studies learning at MI Tamrinul Aulad Kudus is adjusted to the KTSP Curriculum, but for classes I and IV have begun to apply the 2013 Curriculum, (2) The application of problem solving methods in MI NU Tamrinul Aulad Kudus makes students more active thinking, active in learning in the classroom and excited, (3) Factors supporting the problem solving methods, namely: the role of the teacher, the ability to understand the study, student activeness, the effectiveness of the method, students' readiness, and student intelligence. Inhibiting factors of problem solving methods in social studies subjects, namely: lack of student motivation, lack of teacher support, and lack of student concentration.
\end{abstract}

Copyright (C) 2018 Tadris IPS Institut Agama Islam Negeri Kudus. All Right Reserved

\section{Pendahuluan}

Guru sebagai salah satu komponen dalam proses pembelajaran mengemban tugas utamanya yaitu mendidik dan membimbing siswa untuk belajar serta mengembangkan dirinya. Selain itu, guru juga berperan dalam memberikan pengalaman- pengalaman lain untuk membentuk kehidupan sebagai individu yang dapat hidup mandiri di tengah- tengah masyarakat modern.
Pada usia sekolah dasar anak mengalami beberapa perkembangan diantaranya adalah perkembangan intelektual. Pada usia sekolah dasar anak sudah dapat melaksanakan tugastugas belajar yang menuntut kemampuan intelektual atau kemampuan kognitif. Di samping itu, pada akhir masa ini anak sudah memiliki kemampuan dalam memecahkan masalah (problem solving) yang sederhana. Anak mulai memandang dunia secara objektif, bergeser dari satu aspek ke aspek yang lain 
secara reflektif. Anak pada masa usia sekolah dasar akan mendapatkan berbagai rumpun mata pelajaran yang diharapkan mampu mereaksi rangsangan intelektual anak. Salah satu mata pelajaran yang ada pada masa Sekolah Dasar (SD) adalah Ilmu Pengetahuan Sosial (IPS).

Metode Problem Solving merupakan suatu metode dengan cara menyajikan bahan pelajaran dengan menjadikan masalah sebagai titik tolak pembahasan untuk dianalisis dalam usaha mencari pemecahan masalah. Ketika dihadapkan dengan suatu pertanyaan, siswa dapat melakukan keterampilan memecahkan masalah untuk memilih dan mengembangkan tanggapannya. Metode Problem Solving merupakan suatu metode dalam kegiatan pembelajaran dengan jalan melatih siswa menghadapi berbagai masalah, baik masalah pribadi maupun masalah kelompok untuk dipecahkan sendiri atau secara bersama- sama.

Problem Solving mempunyai banyak keunggulan yang dapat membantu memecahkan permasalahan yang kita hadapi dengan merangsang perkembangan kemajuan berpikir siswa untuk menyelesaikan masalah yang dihadapi dengan tepat. Pembelajaran IPS dengan menggunakan metode Problem Solving, diharapkan dapat meningkatkan keterampilan berpikir kritis siswa, menumbuhkan minat sekaligus keaktifan siswa dalam mempelajari IPS, sehingga siswa dapat memperoleh manfaat yang maksimal baik dari proses maupun hasil belajarnya. Walaupun metode tersebut bukan satu-satunya metode pembelajaran IPS yang diterapkan. Namun, dengan metode pemecahan masalah yang diterapkan dalam pembelajaran IPS akan membantu peserta didik dalam proses berpikir mereka dalam memecahkan suatu permasalahan sehingga tujuan pembelajaran IPS yang diterapkan di madrasah tersebut akan tercapai

\section{Metode}

Penelitian ini merupakan jenis penelitian kualitatif atau penelitian lapangan (field research), yaitu penelitian yang dilakukan dengan jalan peneliti terjun langsung ke objek atau ditempat fenomena terjadi, maka data yang didapat akan lebih lengkap, lebih mendalam, lebih kredibel dan bermakna.

\section{Subjek Penelitian}

Informan adalah orang yang dianggap mengetahui dengan baik terhadap masalah yang diteliti dan bersedia untuk memberikan informasi kepada peneliti. Di dalam penelitian kualitatif posisi narasumber sangat penting, sebagai individu yang sangat penting, informasi merupakan tumpuan pengumpulan data bagi peneliti dalam mengungkapkan permasalahan penelitian. Subjek penelitian adalah siswa kelas $\mathrm{V}$ pada pembelajaran IPS yang menerapkan metode problem solving.

\section{Lokasi Penelitian}

Pelaksanaan penelitian di MI NU Tamrinul Aulad Janggalan Kudus pada pembelajaran IPS siswa kelas V.

\section{Teknik Pengumpulan Data}

Teknik pengumpulan data menggunakan teknik observasi dan dokumentasi. Teknik observasi yaitu mengamati kegiatan yang dilakukan siswa pada saat proses pembelajaran IPS menggunakan metode problem solving.

\section{Hasil dan Pembahasan}

Metode problem solving merupakan suatu cara yang menyajikan pelajaran dengan mendorong siswa untuk mencari dan memecahkan suatu masalah atau persoalan dalam rangka pencapaian tujuan pembelajaran. Metode ini sering disebut dengan experiment method, reflective thinking method, atau scientific method.

Metode problem solving juga dikenal dengan metode brainstorming. Ia merupakan metode yang merangsang cara berpikir dan menggunakan wawasan tanpa melihat kualitas pendapat yang disampaikan oleh peserta didik. 
Pendidik disarankan tidak berorientasi pada metode tersebut. Akan tetapi, pendidik hanya melihat jalan pikiran yang disampaikan oleh peserta didik, pendapat peserta didik, dan memotivasi peserta didik untuk mengeluarkan pendapat mereka. Guru tidak boleh tidak menghargai pendapat siswa, meskipun pendapat siswa tersebut salah menurut guru. Orientasi pembelajarannya adalah investigasi dan penemuan yang pada dasarnya adalah pemecahan masalah.

Metode problem solving bukan hanya sekedar metode mengajar tetapi juga merupakan suatu metode berpikir, sebab dalam problem solving dapat menggunakan metodemetode lainnya dimulai dengan mencari data sampai kepada menarik kesimpulan. Metode ini akan melibatkan banyak kegiatan sendiri dengan bimbingan dari guru.

Berdasarkan uraian di atas dapat disimpulkan bahwa metode problem solving adalah sebuah metode pembelajaran yang berupaya membahas permasalahan untuk mencari pemecahan atau jawaban dari permasalahan tersebut dengan mendorong peserta didik untuk mencari dan memecahkan persoalan tersebut. Metode ini sangat baik untuk pembinaan sikap ilmiah kepada para peserta didik.

Kelebihan penggunaan metode problem solving diantaranya adalah siswa akan mampu berpikir secara rasional untuk menghadapi permasalahan yang ada, mendorong siswa menjadi aktif dan berpikir kreatif dalam mencari pemecahan masalah. Selain kelebihan sebagaimana disebutkan di atas metode ini juga memiliki kelemahan diantaranya adalah bahwa penerapan metode ini memerlukan waktu yang cukup lama dibandingkan dengan metode yang lain, tidak semua mata pelajaran terdapat permasalahan yang dapat dicari pemecahan masalahnya, sulit untuk menemukan masalah yang sesuai dengan taraf pemikiran dan perkembangan anak, serta bagi anak yang pasif dan memiliki kemampuan yang kurang akan menyebabkan tertinggal dan kemungkinan akan dapat menyebabkan frustasi dan tekanan batin.

\section{Karakteristik Siswa Sekolah Dasar}

Perkembangan mental pada anak sekolah dasar terutama pada anak kelas atas (usia 9-12 tahun), yang paling menonjol meliputi perkembangan intelektual, bahasa, sosial, emosi, dan moral keagamaan, yang secara perinci dapat dijelaskan sebagi berikut:

\section{a. Perkembangan intelektual}

Pada usia sekolah dasar, anak sudah dapat mereaksi rangsangan intelektual atau melaksanakan tugas- tugas belajar yang menuntut kemampuan intelektual atau kemampuan kognitifnya. Pada akhir masa ini (usia 9-12 tahun) anak sudah memiliki kemampuan memecahkan masalah (problem solving) yang sederhana.

\section{b. Perkembangan bahasa}

Pada anak usia sekolah dasar, perkembangan bahasa minimal mencakup tiga kategori, yaitu (1) dapat membuat kalimat yang lebih sempurna, (2) dapat membuat kalimat majemuk, dan (3) dapat menyusun dan mengajukan pertanyaan.

\section{c. Perkembangan sosial}

Perkembangan sosial berkenaan dengan bagaimana anak berinteraksi sosial. Pada anak usia sekolah mulai memiliki kesanggupan menyesuaikan diri sendiri kepada sikap bekerja sama, dan sikap peduli atau mau memerhatikan kepentingan orang lain.

\section{d. Perkembangan emosi}

Pada masa ini, anak mulai belajar mengendalikan dan mengontrol ekspresi emosinya. Selain itu, pada masa ini, karakteristik emosi anak memiliki emosi yang stabil ditandai dengan menunjukkan wajah yang ceria, bergaul, dengan teman secara baik, dapat berkonsentrasi dalam belajar, bersifat menghargai diri sendiri dan orang lain.

\section{e. Perkembangan moral}

Pada masa ini, anak sudah dapat mengikuti peraturan atau tuntutan dari orang tua atau lingkungan sosialnya. Anak sudah dapat memahami alasan yang mendasari suatu peraturan. Selain itu, anak sudah dapat mengasosiasikan setiap bentuk perilaku dengan konsep benar salah atau baik buruk.

Menurut teori kognitif Piaget, pemikiran anak- anak usia sekolah dasar disebut pemikiran operasional konkrit. Pada masa ini, 
anak sudah mengembangkan pikiran logis. Mereka juga telah mampu menyadari konservasi yakni kemampuan anak untuk berhubungan dengan sejumlah aspek yang berbeda secara serempak. Dengan mengacu pada teori perkembangan kognitif Piaget, dapat diketahui bahwa anak usia sekolah dasar terutama pada usia 9-12 tahun berada pada tahapan operasional konkret. Dimana pada rentang usia ini anak mulai menunjukkan perilaku belajar yang berkembang, yang ditandai dengan ciri- ciri sebagai berikut:

a. Anak mulai memandang dunia secara objektif, bergeser dari satu aspek situasi ke aspek lain secara reflektif dan memandang unsur- unsur secara serentak

b. Anak mulai berpikir secara operasional

c. Anak dapat menggunakan cara berpikir operasional untuk mengklasifikasi bendabenda yang bervariasi beserta tingkatannya

d. Anak mampu membentuk dan menggunakan keterhubungan aturanaturan, prinsip ilmiah sederhana, dan menggunakan hubungan sebab akibat

e. Anak mampu memahami konsep substansi, volume zat cair, oanjang, pendek, lebar, luas, sempit, ringan dan berat.

Para ahli psikologi dan pendidikan menyadari bahwa anak- anak di sekolah tidak hanya harus mengingat atau menyerap secara pasif berbagai informasi baru, melainkan pada masa ini mereka perlu berbuat lebih banyak dan belajar bagaimana berpikir kritis. Karena itu, pendidikan di sekolah haruslah mampu membangun kesadaran kritis anak didik. Manurut Santrock, untuk mampu berpikir secara kritis, anak harus mengambil peran aktif dalam proses belajar.

Berdasarkan beberapa hal tersebut, dapat disimpulkan bahwa seiring dengan masuknya anak ke sekolah dasar, maka kemampuan kognitifnya turut mengalami perkembangan yang pesat. Karena dengan masuk sekolah, berarti dunia dan minat anak bertambah luas, dan dengan meluasnya minat akan bertambah pula pengertian tentang manusia dan objekobjek yang sebelumnya kurang berarti bagi anak. Jika pada masa sebelumnya, daya pikir anak masih bersifat imajinatif dan egosentris, maka pada usia sekolah dasar khusunya pada usia kelas tinggi, daya pikir anak berkembang ke arah berpikir konkrit, rasional dan objektif. Pada masa ini juga anak mulai dapat mengembangkan keterampilan berpikir mereka, diantaranya adalah keterampilan berpikir kritis.

\section{Pembelajaran IPS di MI NU Tamrinul Aulad Kudus}

Pembelajaran merupakan kegiatan yang dilakukan untuk menciptakan suasana atau memberikan pelayanan agar peserta didik belajar. Dalam pembelajaran IPS di MI NU Tamrinul Aulad Kudus, tidak hanya terjadi proses interaksi antara guru dan siswa di dalam kelas. Namun, pembelajaran juga dilakukan dengan berbagai interaksi, baik di lingkungan kelas maupun di luar lingkungan kelas. Peristiwa sosial yang terjadi di masa sekarang maupun masa lampau bisa dijadikan cerminan dalam perbandingan oleh peserta didik.

Pembelajaran IPS di MI Tamrinul Aulad Kudus itu disesuaikan dengan kurikulum yang telah ada. Madrasah ini masih menggunakan Kurikulum KTSP, tetapi untuk kelas I dan IV sudah mulai menerapkan Kurikulum 2013. Akan tetapi untuk madrasah ini walaupun belum sepenuhnya menerapkan pembelajaran berdasarkan Kurikulum 2013, pembelajaran yang berjalan tetap diusahakan menerapkan proses pembelajaran yang hampir seperti Kurikulum 2013, yaitu menerapkan pembelajaran dimana peserta didik yang harus aktif untuk mencari dan membentuk pengetahuan mereka sendiri.

Pembelajaran IPS yang baik dan berkualitas yaitu yang bersifat up to date, maksudnya pembelajaran tersebut selalu mengikuti perkembangan kejadian- kejadian yang ada di sekitar. Oleh karena itu, pada kelas VI semester II di MI NU Tamrinul Aulad Kudus, peserta didik berkewajiban menonton televisi tetapi tetap dibatasi yaitu hanya berkewajiban menonton acara berita saja supaya mereka mendapatkan informasi peristiwa aktul yang sedang terjadi. 
Penerapan metode problem solving pada mata pelajaran IPS di MI NU Tamrinul Aulad Kudus

Metode problem solving merupakan suatu cara yang menyajikan pelajaran dengan mendorong siswa untuk mencari dan memecahkan suatu masalah atau persoalan dalam rangka pencapaian tujuan pembelajaran. Penerapan metode problem solving dalam pembelajaran IPS tidak selalu diterapkan setiap pertemuan, akan tetapi melihat pada materinya terlebih dahulu apakah terdapat permasalahan yang perlu dicari jalan keluarnya atau tidak. Selain itu juga melihat pada tingkat pemahaman peserta didik. Jika peserta didik belum paham tentang materi pada pertemuan sebelumnya, maka akan dijelaskan kembali terkait materi yang mereka belum paham itu.

Langkah penerapan metode problem solving dapat dimulai dari pembahasan materi IPS yang dilakukan pada tahap awal pelaksanaan pembelajaran. Setelah terbentuk suatu pembahasan langkah selanjutnya yaitu seorang guru akan memberikan permasalahan kepada siswa berupa pertanyaan untuk dicari pemecahan masalahnya atau solusi dari permasalahan tersebut. Kemudian siswa mulai mencari jawaban pemecahan masalah tersebut sesuai dengan tingkat pemahaman dan daya berpikir tiap siswa. Disamping siswa sedang mencari, guru akan memberikan bimbingan dan arahan kepada siswa yang merasa kesulitan. Setelah semua sudah selesai, maka guru akan meluruskan jika terdapat kesalahan dari pencarian pemecahan masalah tiap siswa.

Penerapan metode problem solving ternyata dapat mempengaruhi perkembangan keterampilan berpikir siswa. Hal ini dikarenakan dengan adanya masalah, anak kemudian dapat berpikir dan mengembangkan keterampilan berpikirnya dengan baik. Dengan adanya masalah juga, maka anak dapat belajar sehingga dapat memecahkan sebuah permasalahan. Jika anak sudah terlatih dengan diberikan sebuah permasalahan, maka otomatis anak akan terbisa untuk berpikir, terutama sikap berpikir kritis mereka akan terbentuk dan berkembang.
Penerapan metode problem solving juga dapat menumbuhkan keaktifan siswa ketika proses pembelajaran IPS di dalam kelas. Keaktifan siswa merupakan unsur terpenting dalam proses pembelajaran, terutama pembelajaran IPS. Menurut Kamus Besar Bahasa Indonesia menyatakan bahwa aktif berarti giat (bekerja atau berusaha) sedangkan keaktifan adalah hal atau keadaan dimana siswa dapat aktif. Maka guru perlu mencari cara untuk meningkatkan keakatifan siswa. Keaktifan siswa merupakan penggerak dalam kegiatan belajar, karena siswa dituntut untuk aktif dalam proses pembelajaran.

Menurut Nana Sudjana, keaktifan siswa dapat dilihat dari keikutsertaan siswa dalam melaksanakan tugas belajarnya, terlibat dalam memecahkan masalah, bertanya kepada siswa lain atau guru apabila tidak memahami persoalan yang dihadapi, berusaha mencari berbagai informasi yang diperlukan untuk memecahkan masalah, melatih diri dalam memecahkan masalah atau soal, serta menilai kemampuan diri sendiri dan hasil- hasil yang diperoleh.

Penerapan metode problem solving di MI NU Tamrinul Aulad juga dapat menumbuhkan keaktifan peserta didik. Peserta didik lebih sering dan gemar bertanya kepada guru IPS tentang materi atau permasalahn yang mereka miliki. Selain itu, mereka juga aktif di dalam proses pemecahan masalah yang diberikan oleh guru yaitu dengan berusaha mencari berbagai informasi yang diperlukan untuk memecahkan masalah. Mereka berusaha melatih diri untuk memecahkan masalah atau soal yang diberikan.

Faktor pendukung dan faktor penghambat penerapan metode problem solving pada mata pelajaran IPS di MI NU Tamrinul Aulad Kudus

Setiap siswa memiliki sistem konsep yang ada dalam pikiran sebagai hasil pemahaman terhadap objek yang ada dalam lingkungannya. Adanya kelompok intelektualitas juga akan sangat mempengaruhi terbentuknya metode problem solving, meskipun faktor ini tidak dominan. Setiap kelas akan lebih hidup jika adanya orang 
pintar. Mereka juga dapat membantu guru dengan mengajari teman-temannya di luar jam pelajaran.

Secara kompleks penerapan pembelajaran metode problem solving dipengaruhi oleh faktor-faktor berikut: 1) mempertimbangkan aspek kemampuan dan perkembangan peserta didik, 2) peserta didik terlebih dahulu dibekali pengetahuan dan keterampilan yang diperlukan, 3) bimbingan secara kontinu dan persediaan alat- alat atau sarana penajaran yang perlu diperhatikan, 4) merencanakan tujuan yang hendak dicapai secara sistematis dan 5) ketepatan metode. Dari hasil data yang didapat dari observasi dan wawancara, maka faktor pendukung diterapkannya metode problem solving di MI NU Tamrinul Aulad Kudus, yaitu: peran guru, kemampuan untuk memahami kajian, keaktifan siswa, keefektifan metode, kesiapan anak didik, dan kecerdasan siswa.

Pertama, Peran guru sangat penting dalam setiap proses pembelajaran. Baik itu dalam menyampaikan materi di dalam kelas maupun membentuk karakter siswa. Guru menjadi seorang tokoh dan panutan bagi siswa. Oleh karena itu guru harus memiliki standar kualitas tertentu, yang mencakup tanggung jawab, wibawa, mandiri, dan disiplin. Guru di MI NU Tamrinul Aulad Kudus sangat berperan penting dalam menerapkan metode problem solving.

Kedua, kemampuan untuk memahami kajian. Siswa yang mudah menangkap materi yang disampaikan oleh guru akan mudah dalam memahami setiap kajian dalam permasalahan. Dalam penerapan metode problem solving pada mata pelajaran IPS, siswa dilatih untuk memahami setiap kajian dalam permasalahan yang diberikan oleh guru.

Ketiga, keaktian siswa. Pada metode problem solving ini, siswa dilatih untuk menunjukkan keaktifannya. Dimana siswa akan diberikan materi terlebih dahulu yang kemudian mereka diberikan sebuah permasalahan dan mereka bertugas mencari pemecahan masalahnya. Siswa akan mulai bepikir dan mencari pemecahan jalan keluarnya sesuai kemampuan mereka sendiri.
Keempat, keefektifan metode. Metode problem solving ini sudah cukup efektif diterapkan di MI NU Tamrinul Aulad Kudus. Metode ini mampu menghantarkan siswa mencapai tujuan-tujuan instruksional yang telah ditetapkan, meningkatkan minat belajar siswa. Sehingga prestasi siswa sampai saat ini banyak yang mengalami peningkatan. Selain itu, keterampilan berpikir kritis, keaktifan siswa dan minat belajar mereka juga mulai mengalami perkembangan. Hal ini dapat dilihat ketika mereka mulai aktif bertanya di kelas dan aktif mencari pemecahan masalahnya. Selain itu juga mereka semakin bersemangat selama proses pembelajaran di kelas.

Kelima, kesiapan anak didik. Hal ini tentu sangat berpengaruh terhadap penerapan metode ini. Apabila peserta didik belum siap dalam proses pembelajaran, maka mereka tidak mungkin akan bisa menerima materi pelajaran dengan mudah. Mereka juga tidak akan mungkin dapat diterapkan berbagai metode yang ada, karena ketika mereka belum siap dalam menerima materi pelajaran, hal ini menjadikan mereka tidak akan focus pada kegiatan belajar mengajar. Jadi, ketika guru memberikan penjelasan, mereka mungkin akan gaduh sendiri. Berbeda ketika mereka sudah siap ketika pembelajaran, mereka akan focus dengan penjelasan yang diberikan guru.

Keenam, kecerdasan siswa. Siswa yang cerdas akan mudah untuk diarahkan dan dibimbing. Cenderung guru akan merasa lebih senang dengan siswa yang memiliki kecerdasan tinggi. Dengan tidak pilih-pilih, guru juga akan memperhatikan siswa yang memiliki kecerdasan kurang. Guru akan menyeimbangkan antara keduanya.

Dalam pembelajaran efektif dan bermakna, peserta didik perlu dilibatkan secara aktif, karena mereka adalah pusat dari kegiatan pembelajaran serta pembentukan kompetensi, dan karakter. Salah satu sasaran pembelajaran adalah membangun gagasan saintifik setelah siswa berinteraksi dengan lingkungan, peristiwa, dan informasi dari sekitarnya. Agar peserta didik belajar secara aktif, guru juga perlu menciptakan strategi yang tepat 
sedemikian rupa agar mereka mempunya motivasi yang tinggi untuk belajar.

Kelemahan dari pembelajaran dengan metode problem solving adalah penerapan metode ini memerlukan waktu yang cukup lama dibandingkan dengan metode yang lain, tidak semua mata pelajaran terdapat permasalahan yang dapat dicari pemecahan masalahnya, sulit untuk menemukan masalah yang sesuai dengan taraf pemikiran dan perkembangan anak, serta bagi anak yang pasif dan memiliki kemampuan yang kurang akan menyebabkan tertinggal dan kemungkinan akan dapat menyebabkan frustasi dan tekanan batin. Sedangkan faktor penghambat dalam menerapkan metode problem solving di MI NU Tamrinul Aulad pada mata pelajaran IPS, yaitu:

Pertama, kurangnya motivasi siswa. Sebagian siswa yang kurang termotivasi dalam setiap pembelajaran akan menjadi penghambat dalam penerapan metode problem solving. Tidak semua siswa memiliki motivasi tinggi, sehingga guru harus pandai dalam memberikan materi pembelajaran, khususnya materi mata pelajaran IPS. Solusi dalam mengatasi faktor penghambat ini yaitu guru harus memberikan motivasi seperti memberikan siswa semangat untuk terus belajar dan memberikan nasihat-nasihat supaya mereka dapat termotivasi untuk belajar.

Kedua, kurangnya dukungan guru. Dalam penerapan metode problem solving, dukungan guru juga sangat dibutuhkan. Untuk mengatasi faktor penghambat ini, guru harus sering memperhatikan siswanya. Membiarkan siswa untuk bereksperimen, agar siswa lebih percaya diri dengan kemampuannya. Salah satu cara yang dapat dilakukan adalah guru memberikan tugas-tugas kepada siswa dan membiarkan siswanya untuk mencoba menyelesaikan permasalahan tersebut terlebih dahulu, baru setelah itu guru akan memberikan bimbingan dan meluruskan dari jawaban yang diungkapkan peserta didik.

Ketiga, kurangnya konsentrasi siswa. Siswa yang pendiam sebagian besar dia menjadi penakut dan kurang konsentrasi. Karena dia takut untuk mencoba. Siswa yang penakut harus diarahkan dengan sabar, sehingga dia tidak mudah tersinggung dengan kata-kata guru yang kurang diterima oleh siswa. Dalam mengatasi sikap takut siswa ini, guru harus menanamkan sikap pemberani kepada siswa. Siswa lebih diperhatikan dan dilatih untuk menjadi siswa yang lebih berani untuk mencoba. Dalam mengatasi kurangnya konsentrasi dari siswa, maka guru harus pandai dalam menguasai emosi siswa. Ketika siswa mulai konsentrasinya berkurang, maka guru harus mencari cara untuk meningkatkan kembali konsentrasi dari siswa. Salah satu cara yang dapat dilakukan adalah dengan menggunakan ice breaking seperti nyanyian atau tepuk- tepuk semangat. Selain itu dapat juga dengan menceritakan sebuah kisah yang berkaitan dengan materi.

\section{Simpulan}

Berdasarkan hasil penelitian yang telah dilakukan oleh peneliti, maka kesimpulannya adalah Pembelajaran IPS di MI Tamrinul Aulad Kudus itu disesuaikan dengan kurikulum yang ada. Madrasah ini masih menggunakan Kurikulum KTSP, tetapi untuk kelas I dan IV sudah mulai menerapkan Kurikulum 2013. Akan tetapi untuk madrasah ini walaupun belum sepenuhnya menerapkan pembelajaran berdasarkan Kurikulum 2013, pembelajaran yang berjalan tetap diusahakan menerapkan proses pembelajaran yang hampir seperti Kurikulum 2013, yaitu menerapkan pembelajaran dimana peserta didik yang harus aktif untuk mencari dan membentuk pengetahuan mereka sendiri. Ketika proses mengajar tetap berpedoman pada Rencana Pelaksanaan Pembelajaran (RPP).

Penerapan metode problem solving di MI NU Tamrinul Aulad Kudus pada mata pelajaran IPS menjadikan siswa lebih aktif berpikir sehingga tiap peserta didik dapat mengasah kecerdasan. Metode ini mampu mengembangkan keterampilan berpikir siswa. Selain itu dapat menumbuhkan keaktifan siswa di dalam kelas selama proses pembelajaran karena menjadikan peserta didik lebih aktif di dalam bertanya. Hal lain yang muncul ketika metode tersebut diterapkan adalah 
menumbuhkan minat belajar peserta didik terhadap IPS, yang awalnya mereka merasa jenuh dan bosan menjadi lebih bersemangat kembali setelah diterapkan metode tersebut.

Faktor pendukung diterapkannya metode problem solving di MI NU Tamrinul Aulad Kudus, yaitu: peran guru, kemampuan untuk memahami kajian, keaktifan siswa, keefektifan metode, kesiapan anak didik, dan kecerdasan siswa. Sedangkan faktor penghambat dalam menerapkan metode problem solving di MI NU Tamrinul Aulad Kudus pada mata pelajaran IPS, yaitu: kurangnya motivasi siswa, kurangnya dukungan guru, dan kurangnya konsentrasi siswa. Untuk mengatasi faktor penghambat yang pertama adalah guru harus memberikan motivasi seperti memberikan siswa semangat untuk terus belajar dan memberikan nasihat- nasihat supaya mereka dapat termotivasi untuk belajar. Solusi untuk mengatasi faktor penghambat yang kedua adalah guru memberikan tugastugas kepada siswa dan membiarkan siswanya untuk mencoba menyelesaikan permasalahan tersebut terlebih dahulu, barulah setelah itu guru akan memberikan bimbingan dan meluruskan dari jawaban yang diungkapkan peserta didik. Dalam mengatasi kurangnya konsentrasi dari siswa, maka guru harus pandai dalam menguasai emosi siswa. Ketika siswa mulai konsentrasinya berkurang, maka guru harus mencari cara untuk meningkatkan kembali konsentrasi dari siswa. Salah satu cara yang dapat dilakukan adalah dengan menggunakan ice breaking seperti nyanyian atau tepuk- tepuk semangat. Selain itu dapat juga dengan menceritakan sebuah kisah yang berkaitan dengan materi.

\section{Saran}

Berdasarkan simpulan di atas, maka yang menjadi saran dalam penulisan ini adalah pengembangan metode pembelajaran harus terus ditingkatkan untuk menyesuaikan dengan kondisi dan kebutuhan siswa agar dapat meningkatkan kemampuan berikir kritis siswa khususnya pada pembelajaran IPS.
Aqib, Zainal dan Ali Murtadlo. 2016. Kumpulan Metode Pembelajaran Kreatif dan Inovatif. Bandung: Sarana Tutorial Nurani Sejahtera.

Desmita. 2012. Psikologi Perkembangan. Bandung: Remaja Rosdakarya.

Hamdani. 2010. Strategi Belajar Mengajar. Bandung: Pustaka Setia.

Perdana, Mayang Putri. "Pengaruh Metode Problem Solving terhadap Hasil Belajar Siswa Kelas VIII MTs Asysyafi'iyah Gondang pada Materi Hubungan Sudut Pusat, Panjang Busur, dan Luas Juring dalam Pemecahan Masalah". IAIN Tulungagung.

Pusat Pembinaan dan Pengembangan Bahasa. 1998. Kamus Besar Bahasa Indonesia. Jakarta: Perum Balai Pustaka.

Sardiman. 2011. Interaksi dan Motivasi Belajar Mengajar. Jakarta: Raja Grafindo.

Sudjana, Nana. 2002. Dasar- Dasar Proses Belajar Mengajar. Bandung: Sinar Baru Algensindo. Bandung.

2005. Hasil dan Proses

Belajar Mengajar. Bandung: Remaja Rosdakarya. Bandung.

Susanto, Ahmad. 2015. Teori Belajar dan Pembelajaran di Sekolah Dasar. Jakarta: Prenadamedia Group.

Sugiyono. 2005. Memahami Penelitian Kualitatif. Bandung: Alfabeta.

Wahyudi, Agung. "Meningkatkan Kemampuan Berpikir Kreatif Siswa Dalam Belajar Matematika Dengan Menggunakan Pendekatan Pemecahan Masalah (Problem Solving) Pada Siswa Kelas VII D SMPN 2 Depok". Universitas Negeri Yogyakarta.

Yamin, Martinis. 2004. Strategi Pembelajaran Berbasis Kompetensi. Jakarta: Gaung Persada Press.

\section{Referensi}

